\title{
Distribution of the fungus-gardening ant (Trachymyrmex septentrionalis) during and after a record drought
}

\author{
JON N. SEAL and WALTER R. TSCHINKEL Department of Biological Science, Florida State \\ University, Tallahassee, FL 32306, USA
}

\begin{abstract}
Insects are known to be influenced by global climate change, especially by drought and increased temperatures.

2. Although ants are widely regarded to be indicator or keystone species and ecosystem engineers, we do not know how ants may respond to global climate change.

3. This study reports the range contraction of an extremely abundant fungus-gardening ant (Trachymyrmex septentrionalis) over a 3-year period that coincided with the end of a record drought in southeastern North America.

4. Reduction in nest number appears to be the result of an increase in water-table levels and decrease in soil aridity.

5. Therefore T. septentrionalis should be expected to increase its abundance and presumably its ecological impact during multiyear droughts.
\end{abstract}

Key words. Attini, climate change, El Niño, ENSO, global warming, La Niña, nest architecture, Pinus palustris, Quercus laevis, water table.

\section{Introduction}

Global warming and changing of hydrological regimes are thought to have profound consequences on the distribution and abundance of ectotherms such as insects (Chown \& Nicholson, 2004). Droughts associated with climate warming can have negative effects by reducing breeding success (Pollard et al., 1997) and causing insects to leave preferred habitat and occupy inferior ones (Kindvall, 1995). Generally, mobile species or those capable of tolerating a wide range of temperatures are expected to fare better than less mobile species or those specialised to certain conditions (Parmesan, 2006; Deutsch et al., 2008). In some cases, a warmer climate may have positive consequences on species that occupy the margins of their distribution, which may in fact expand their ranges if they are capable of dispersal (Thomas et al., 2001). For example, odonates (dragonflies and damselflies) in the Netherlands have advanced their flight times to earlier in the year (Dingemanse \& Kalkman, 2008) and some temperate Lepidoptera (moths, skippers and butterflies) and Odonata are expanding their ranges northward (Parmesan et al., 1999; Hickling et al., 2005; Parmesan, 2006).

Outside the Lepidoptera and Odonata, much less is known about the consequences of increased temperatures and droughts

Correspondence: Jon N. Seal, Integrative Biology, University of Texas at Austin, 1 University Station \#C0930, Austin, TX 78712, USA. E-mail: trachymyrmex@googlemail.com on other insect taxa. Ants are widely regarded as keystone members and ecosystem engineers in many ecosystems because of their known contributions to ecoystem processes (Andersen, 1997; Agosti et al., 2000; MacMahon et al., 2000; Jiménez \& Decaëns, 2006; Jouquet et al., 2007; Cammeraat \& Risch, 2008; Jiménez et al., 2008) yet their responses to climate change are unknown (Underwood \& Fisher, 2006). Ants often exhibit considerable inter-specific variation in heat tolerance and desiccation resistance, which has many consequences in terms of their distribution and community structure (Brian \& Brian, 1951; Elmes \& Wardlaw, 1982a,b; Hood \& Tschinkel, 1990; Cerdá et al., 1998; Kaspari et al., 2000; Lubertazzi \& Tschinkel, 2003; Delsinne et al., 2008). The responses of ant populations to climate change could be quite different from other insects because the mature forms are comparatively sessile entities and, once established, nest movements tend to be local (Carlson \& Gentry, 1973; Harrison \& Gentry, 1981; Bourke \& Franks, 1995; Banschbach \& Herbers, 1999; McGlynn et al., 2004). Longer distances are often travelled by single inseminated winged females dispersing from natal nests and founding nests solitarily or in groups of other females (Bourke \& Franks, 1995; Tschinkel, 2006). Consequently, should an environment change for the worse, populations could suffer high mortality, if not become locally extinct, which would thus potentially alter ecosystem function.

Periodic warming or cooling of oceanic surface water known as El Niño/Southern Oscillation events have global and regional

(C) 2010 The Authors Journal compilation (c) 2010 The Royal Entomological Society 
consequences by altering regional patterns of rainfall (NOAA: Climate Prediction Data Center, 2009). In southeastern North America, these periods are associated with increased rainfall and are often followed by a drier and warmer period (La Niña). The 'La Niña' that occurred 1998-2002 brought record high temperatures and drought, which caused reductions in surface water and lowered water tables to their lowest levels in close to a century (Lawrimore et al., 2001; Beckage et al., 2003; Verdi et al., 2006; NOAA: Climate Prediction Data Center, 2009). Consequences included population crashes of amphibians (Means, 2007), exceptional mortality in aquatic vertebrates (Aresco, 2005) and coastal stands of trees due to sea-level rise (Williams et al., 2003, 2007) and increased susceptibility to fire (Beckage et al., 2003). Droughts ceased and aquifers began to recover in 2003 and 2004 (Verdi et al., 2006).

Longleaf pine forests once dominated the Atlantic and Gulf coastal plains, but today occupy only $3 \%$ of their historical range (Frost, 1993; Platt, 1999). Although these forests are characterised by low topographical relief, elevation gradients on the scale of centimetres have pronounced consequences on physical and biological characteristics (Platt, 1999; Whitney et al., 2004). Areas with a shallow water table $(<1 \mathrm{~m})$ (the flatwoods) generally have plants and animals adapted to wet conditions and even periodic flooding, such as gallberry (Ilex glabra) (Abrahamson \& Harnett, 1990). In contrast, areas with a deep water table $(>1.5 \mathrm{~m})$ (the sandhills) have plants and animals adapted to xeric conditions (Waite, 1984; Abrahamson \& Harnett, 1990; Brown et al., 1990; Chen \& Gerber, 1990; Myers, 1990), such as prickly pear cactus (Opuntia humifusa) and drought resistant oaks, especially turkey oak, Quercus laevis (Myers, 1990; Long \& Jones, 1996; Espeleta \& Donovan, 2002). Characteristic animals include the gopher tortoise (Gopherus polyphemus), eastern diamondback rattlesnake (Crotalus adamanteus), the Florida seed-harvesting ant (Pogonomyrmex badius) and the fungus-gardening ant, Trachymyrmex septentrionalis McCook (Myers, 1990; Tschinkel, 1999; Seal \& Tschinkel, 2006; Waldron et al., 2008). These species are close relatives of western species, which are thought to have arrived during interglacial periods from western prairies and deserts when the climate was more arid than today (Johnson, 2001; Whitney et al., 2004; Rabeling et al., 2007). It should be noted that of these, T. septentrionalis extends its range well into Texas and thus appears to be tolerant of conditions more arid than normally experienced in southeastern pine forests (Rabeling et al., 2007).

Soil hydrology and temperature probably have pronounced consequences on the distribution of ants that have subterranean nests. Nest architecture is generally an important feature of ant colonies (Tschinkel, 1987, 2003, 2004, 2005; Hölldobler \& Wilson, 2008). In northern Florida, species that excavate deep nests in soil such as Solenopsis geminata, Prenolepis imparis, Pogonomyrmex badius and T. septentrionalis are rarely ever found in the flatwoods, but are among the most common ants encountered in sandhills. Species that have nests closer to the surface, such as several Formica species and Aphaenogaster treatae are largely absent from sandhills and are most common in the flatwoods (Tschinkel, 1988; King \& Trager, 2007) (J. R. King \& W. R. Tschinkel, unpubl. data). Trachymyrmex septentrionalis in particular has an architecture that reflects its obligate dependence on symbiotic fungi (Mueller et al., 2001), which in turn determines where this species may occur. The fungus appears to have narrow temperature and humidity requirements (Powell \& Stradling, 1986; Roces \& Kleineidam, 2000; Bollazzi \& Roces, 2002; Bollazzi et al., 2008). Compared to most other ants that have subterranean nests, which may have hundreds of tunnels and chambers, $T$. septentrionalis nests are highly simplified by having one or few chambers (Tschinkel, 2003). The location of the chambers fluctuates seasonally; their deepest levels are reached during summer (June-August) $(>1 \mathrm{~m})$ and the shallowest the rest of the year (ca. $30 \mathrm{~cm}$ ) (Seal \& Tschinkel, 2006). Presumably, this digging behaviour tracks ideal temperatures for their symbiont (Seal \& Tschinkel, 2006; Bollazzi et al., 2008) and/or humidity (Roces \& Kleineidam, 2000). Consequently, in areas where the water table is closer to the surface (the flatwoods), the ants may not be able to relocate their garden because areas of suitable humidity and temperature may be flooded. Similarly, should water-table levels rise, colonies can drown or lack sufficient vertical soil volume in which to move their garden in the search of appropriate conditions.

The following study presents distribution data of the fungusgardening ant, $T$. septentrionalis, in a longleaf pine forest located in northern Florida. This region is considered one of North America's biodiversity hotspots due to its high species richness of plants, insects, amphibians and reptiles, which includes several endemic and listed species (Deyrup \& Lubertazzi, 2001; Whitney et al., 2004; King \& Trager, 2007; Blaustein, 2008). Trachymyrmex septentrionalis is extremely abundant in these forests with over 1000 nests per hectare that together excavate nearly 1 MT of soil each year, making it an important species in these nutrient-poor and relatively unproductive forests (Seal \& Tschinkel, 2006). We have proposed previously that its abundance and positive correlations with characteristic features of longleaf pine sandhills make it an insect indicator species for these forests (Seal \& Tschinkel, 2006). In this study, we describe the distribution of this species during 2001 and again in 2004 along $14 \mathrm{~km}$ of transects $\left(>27000 \mathrm{~m}^{2}\right)$. This time period spanned the end of the extremely dry 'La Nina' period during 1998-2002 (Verdi et al., 2006). We present a descriptive dataset that suggests that this global climate phenomenon indeed affected the population of this ant.

\section{Materials and methods}

\section{Study regions}

Study populations were located in the Wakulla Ranger District (WRD) of the Apalachicola National Forest (ANF) $\left(30^{\circ} 22^{\prime} \mathrm{N}, 84^{\circ} 22^{\prime} \mathrm{W}\right)$, which has been summarised previously (Seal \& Tschinkel, 2006, 2007). In May 2001, over $14 \mathrm{~km}$ of the ANF were surveyed by walking along transects through longleaf pine habitats. All of these transects were located in compartments (unit of management of the USDA Forest Service) that had been burned in April 2001, giving a clear view of the ground. These compartments are on a 3-year 'growing-season' burn schedule (M. Dueitt, pers. comm.), which takes place in the period of April-June; historically the warmest and driest period in 
the southeast and the most prone to intense, but small scale fires (Glitzenstein et al., 1995; Platt, 1999). Nevertheless, the characteristics of each site were somewhat unique in terms of groundcover and types of tree species, as ecologically based forest management has only been practiced for approximately the past two decades. Thus, many areas still contain vestiges of less ecologically sound management practices, such as clear-cutting and the planting of slash pine (Pinus elliottii).

Transects were located in five broad regions (Fig. 1) in approximately most of the WRD of the ANF. These regions included areas entirely within sandhills habitat ('Crawfordville' and a section behind Lost Lake Recreation Area) and regions of flatwoods habitat containing areas of topographic relief ['Cutoff', 'Ant Paradise' and 'Borrow Pit' (Fig. 1)] and accordingly sandhill-like habitat on higher regions.

\section{Spatial distribution of nests}

Every nest of $T$. septentrionalis and its approximate location (in increments of $25 \mathrm{~cm}$ ) was recorded that occurred within a 2-m swath along either side of each transect. Colonies of this species excavating soil into crescent-shaped tumuli (Tschinkel \& Bhatkar, 1974; Seal \& Tschinkel, 2006, 2008), making these nests easy to identify. Colonies were counted well after the end of dormancy (mid-February to early March) and before mating flights, which take place in late May-early June (Seal \& Tschinkel, 2007). Thus, all nests were at least 1 year old. As young and old nests exhibit similar seasonal digging behaviour (Seal \& Tschinkel, 2006, 2008; J. N. Seal, unpubl. data), it is likely that all nests in each transect were counted. Each transect was walked in a single compass heading until further progress was impeded by swamps or paved highways. In most cases, parallel transects were walked that were at least $100 \mathrm{~m}$ apart. The average transect length was $395 \mathrm{~m}$ and ranged from 211 to $705 \mathrm{~m}$. We took GPS coordinates of the terminus of each transect and also marked them with flagging tape and noted distances to recognisable landmarks (e.g. large trees, signs, etc.). Transect length was estimated by counting the number of steps for the first author to walk $50 \mathrm{~m}$. Thus, transect length was obtained by counting the number of steps between each terminus. Many of the first transects had their lengths measured twice to make sure distances were accurate. Nests were then counted using a hand counter.

After the vegetation had regrown by late summer, each transect was re-walked in October 2001 noting only the type of vegetation (ant nests were not counted). The vegetation was classified broadly as to the type of common plant gallberry, runner oak (Quercus minima), or turkey oak, with gallberry occurring nearest to the swamps and turkey oak in the driest parts with runner oak occurring in a transitional area in between.

All transects were surveyed again in May 2004 to determine whether the population sizes changed during this 3-year period. These transects had been burned again the preceding April, giving us a clear view of the ground. Each ant nest was simply counted and not mapped in 2004. As it became quickly obvious that nest numbers had changed in the 3-year period, several of the first transects were re-walked to be certain that nest counts were accurate. Additionally, the location of the first and last ant nest on each transect was noted.

\section{Statistical analyses}

Comparisons of nest densities in 2001 by habitat type were $\log _{10}$ transformed prior to analysis to meet parametric assumptions. Paired $t$-tests were used to analyse differences among years. Post hoc power tests were conducted using G-Power (Faul, 2008), otherwise all analyses were conducted using STATISTICA version 6 (Statsoft, 2003). High power indicates a low probability of making a Type II error (failing to reject a hypothesis when it is not true) (Sokal \& Rohlf, 1995). To facilitate comparisons of means among groups, we calculated Cohen's $d$-statistic,

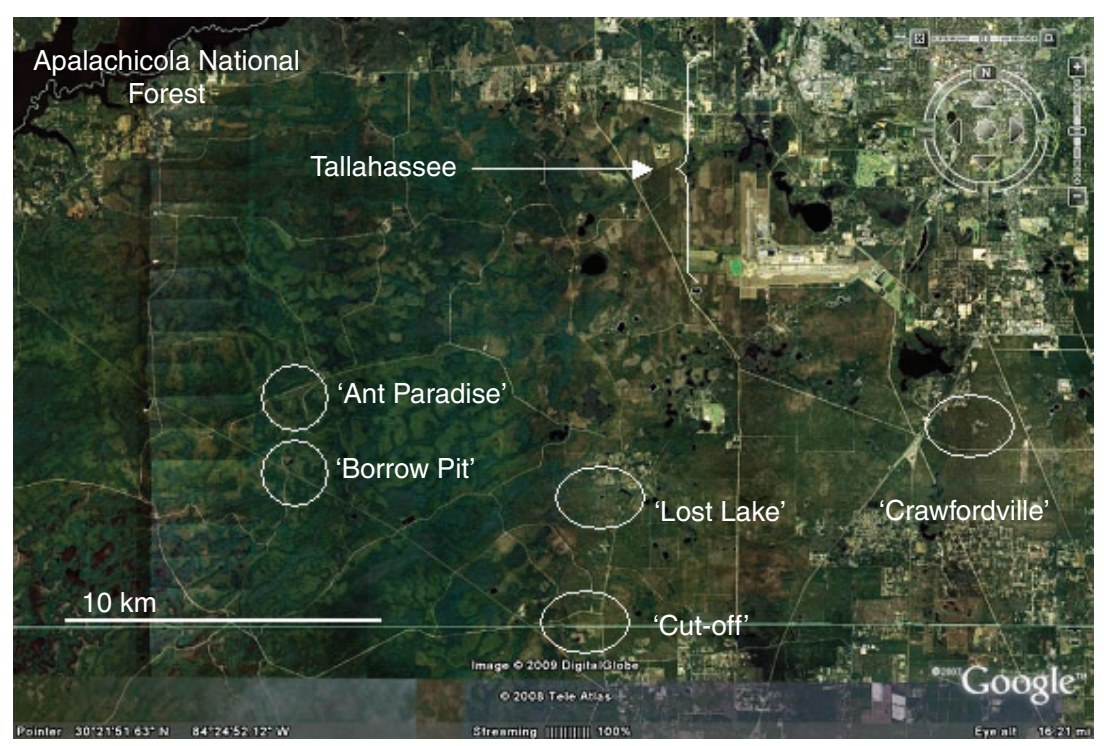

Fig. 1. Map of the Apalachicola National Forest, Wakulla District.Circles indicate the areas surveyed. The dark green areas to the left generally correspond to the wetter flatwoods whereas lighter green and brown areas to the right are the drier Munson Sandhills. Scale in lower right corner. Photo courtesy of Google Earth.

(C) 2010 The Authors Journal compilation (C) 2010 The Royal Entomological Society, Insect Conservation and Diversity, 3, 134-142 
which is a standardised mean difference or effect size. This value provides the amount of variation in a parameter and a measure of its biological relevance, whereas a $P$-value provides only a simple 'yes-no' answer. Cohen's $d$-values around 0.2 indicate small effects, 0.5 , medium effects and $>0.8$ correspond to large effects (Nakagawa \& Cuthill, 2007).

\section{Results}

\section{Distribution of nests in 2001}

Nests were most abundant in areas of higher elevation and presumably drier soils because their distribution overlaps almost entirely with plants adapted to xeric conditions (Fig. 2), such as turkey oaks. Nests extended outwards from these areas into an ecotone that merged with the lowest part of the flatwoods abutting the titi swamps. This ecotone lacked turkey oaks, but was covered with a dense groundcover of runner oak. With few exceptions, nests were completely absent by the time the runner oak groundcover was replaced by gallberry. All the nests found in the gallberry zone were found on high $(\mathrm{ca} .1 \mathrm{~m})$ earthen berms constructed for fire management.

Comparisons indicated that neither nest number $\left(F_{4,9}=0.29, P=0.88\right)$, area surveyed $\left(F_{4,9}=1.78, P=\right.$ $0.22)$ nor nest density $\left(F_{4,9}=0.89, P=0.51\right)$ differed significantly among the five study regions surveyed. On the other hand, nests were most abundant in the turkey and runner oak zones and least abundant in road rights of way, dried pond bottoms and gallberry zones (Fig. 3a). Density of nests was highest in the turkey-oak zones but variation among the other habitat zones was not significant (Fig. 3b). With the exception of dry pond beds and roadsides, which were underrepresented, the area surveyed (sampling effort) was similar for gallberry, runner and turkey-oak zones (Fig. 3c). One caveat with these analyses is that the main effects of sampling region and habitat zone could not be analysed in the same model for possible interactions among habitat region and habitat zone.

\section{Distribution of nests in 2004}

The total number of nests and population density decreased from a total number of 3233 nests in 2001 to 2905 nests in 2004 or by about $11 \%$. This appears to be a consequence of the inhabited zone shrinking by about $9 \%$, whereas the density of nests in these zones did not significantly change (Table 1). Of the few nests found in the gallberry zones in 2001, none were present in 2004. The same was true for colonies found in dry pond beds in 2001, even though in 2004 at the time of surveys, the ponds contained no water. Comparisons among the five regions suggest that these reductions occurred in the flatwoods (Ant Paradise, Borrow Pit and Cut-Off) whereas in the two sandhill regions (Lost Lake and Crawfordville) population increases occurred. Even though none of these latter tests are statistically significant due to lack of power, the small to medium effect sizes could be indicative of biological significance, which would thus merit future study (Table 2).

Rainfall recorded at Tallahassee Regional Aiport in 2000 was the driest year of the preceding two decades in Tallahassee (Fig. 4a) [data from the US National Weather Service (http:// www.weather.gov/climate/index.php?wfo=tae)]. The slightly above average amount of rainfall in 2001 was largely the result of two tropical storms (Tropical Storms Allison and Barry) that each dumped 25.73 and $22.63 \mathrm{~cm}$ of rain in 24-h periods, respectively, after nest counts were completed in 2001. Although no tropical systems passed through the area in the two subsequent years, the summer of 2003 was wetter than average (Fig. 4b).

\section{Discussion}

Despite recognition that ants are important in many ecological processes (Tobin, 1994; Folgarait, 1998; MacMahon et al., 2000; Davidson et al., 2003), to our knowledge this is the first study that describes the possible consequences of a global phenomenon on the distribution of an ant population. Ant nest numbers appear to be lower in years with normal or above normal amounts of rainfall and nest numbers are higher in drier
Fig. 2. Map of 'Ant Paradise' in compartment 231 of the ANF in 2001. This area was characterised by an area of higher relief surrounded by gallberry and titi swamps. Trachymyrmex septentrionalis nests are indicated by black points and were largely restricted to the central higher portion. The few cases where they were outside of this region occurred on tall earthen berms created by the USDA forest service as fire breaks. Hatched lines indicate road paths. Grey indicates unsurveyed titi swamp. Axes indicate distances from arbitrary origins measured in metres (Cartesian coordinate scale).

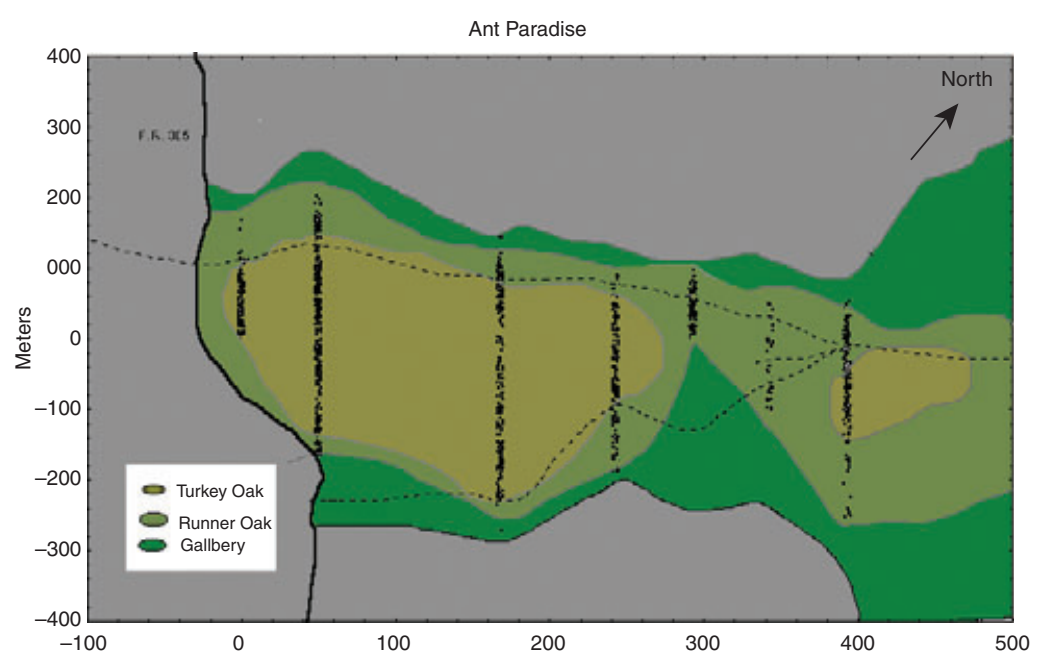




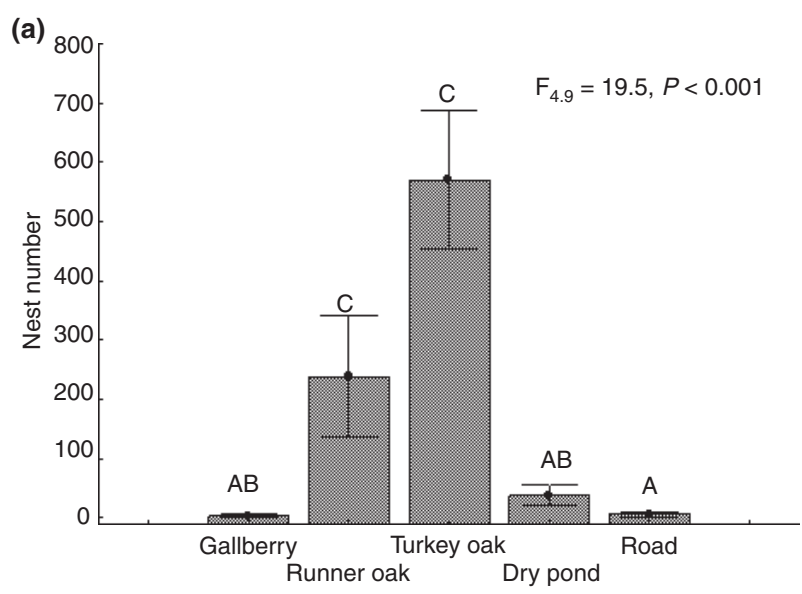

(b)

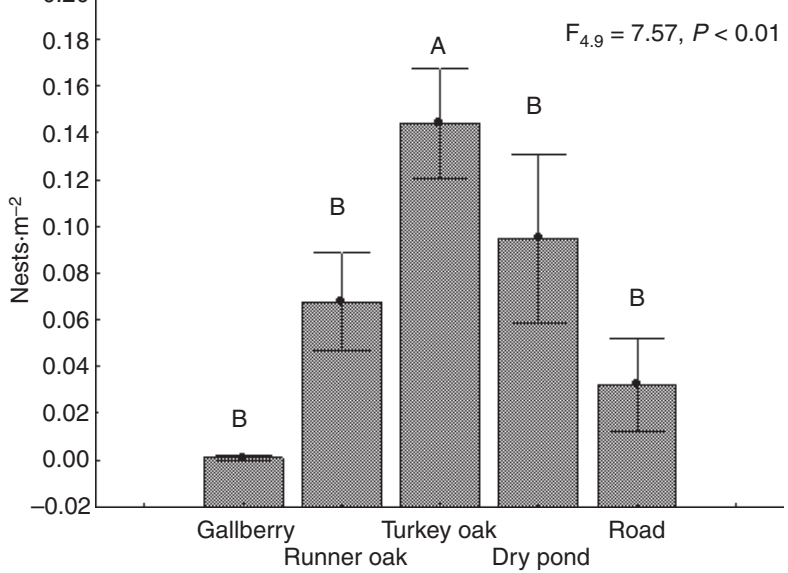

(c)

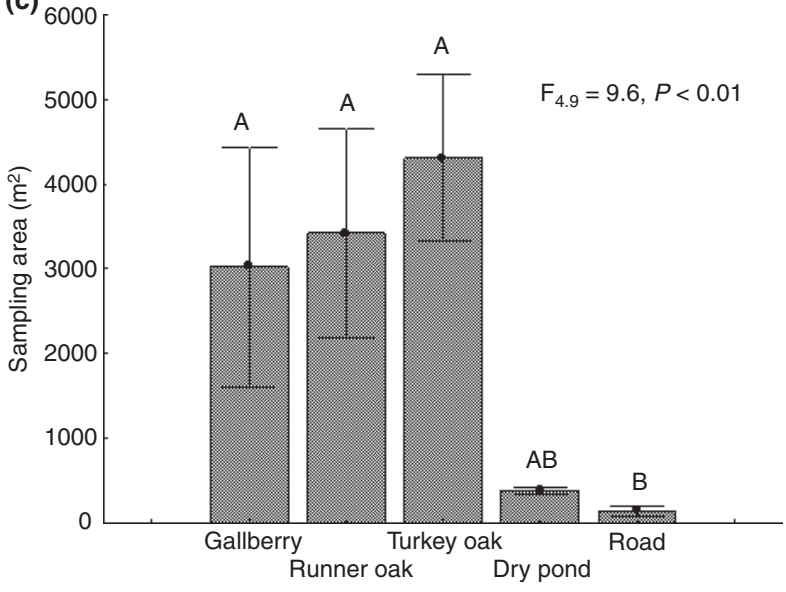

Fig. 3. (a) Mean nest number in each habitat zone ( \pm SE) in 2001. (b) Mean nest density in each habitat zone $( \pm$ SE) in 2001. (c) Mean surveyed area of each habitat zone $( \pm$ SE) in 2001. Categories sharing similar letters are not significantly different $(P<0 \cdot 05$, Scheffe's test $)$.

years. Thus, it would seem that propagule pressure is sufficient to increase population size during multiyear droughts. Conditions later change during wet years so that either propagules pressure decreases and/or mortality increases. This study suggests that even though droughts in the southeast are generally considered to have negative effects on native flora and fauna (Williams et al., 2003; Aresco, 2005; Means, 2007), sandhill species such as $T$. septentrionalis perhaps thrive under drier than normal conditions.

Proximity to the water table is thought to have important consequences on plant communities in southeastern forests (Abrahamson \& Harnett, 1990; Myers, 1990; Platt, 1999; Whitney et al., 2004) and presumably soil-dwelling ants (J. R. King \& W. R. Tschinkel, unpubl. data) (Tschinkel, 1987, 1988, 2003, 2004, 2005; Hölldobler \& Wilson, 1990; King \& Trager, 2007). Colonies of $T$. septentrionalis were most abundant and populations denser in turkey oak woodlands, which is where the water table is generally the lowest (J. N. Seal \& W. R. Tschinkel, unpubl. data). Turkey and other sandhill oaks are intolerant of waterlogged soils (Long \& Jones, 1996; Espeleta \& Donovan, 2002). Although we did not start measuring water-table levels until 2005 (W. R. Tschinkel \& J. N. Seal, unpubl. data), we have good reason to believe that the drought strongly influenced ground water levels in the ANF. Most of the ponds in the ANF are fishless, temporary and thus usually dry for at least part of the year. During the drought, many of the temporary ponds found in the Munsion Sandhills region were dry for abnormally long periods ( $>12$ consecutive months), which resulted in amphibian population crashes and local extinctions (Means, 2007). Another observation strongly supporting the importance of water-table levels is that all colonies we observed in 2001 in the dry pond bottoms and in the gallberry zones were absent from these areas in 2004.

While fires could cause mortality of foragers and thus depress colony performance and eventually reduce population sizes, colonies are presumably insulated from the immediate impacts of fire, because colonies keep their fungus garden well below the soil surface (Seal \& Tschinkel, 2006, 2008). Fire could incinerate fungal substrates (food); however, excavations of nests in recently burned and unburned areas did not reveal differences in terms of colony size or sexual production (J. N. Seal, unpubl. data). Fires probably enhance colony performance by increasing exposure to sunlight and removing vegetation that would shade and cool the soil, such as oaks and other woody shrubs, because shady areas have cooler soils and have smaller and extremely unproductive colonies (Seal \& Tschinkel, 2006). In contrast, areas that have open canopies and high amounts of pine biomass (correlated traits of a frequent burn regime), generally have larger and more productive colonies (Seal \& Tschinkel, 2006).

We can also exclude colony movements as another possible explanation for the reduction in nest number. Even though $T$. septentrionalis colonies have been observed to move their nests (including fungus garden), this occurs on the scale of 1-3 m (J. N. Seal, unpubl. data). Considering that the flatwoods sites are essentially islands of higher ground surrounded by lower, wetter areas, the only place for colonies to migrate would be towards the centre of the dome, which would have resulted in a population increase - the exact opposite to what we observed. It is of course possible that colony migration was followed by population decreases in a density-dependent mechanism, which is supported by the finding that the density of nests in the transects did not differ between years, whereas nest number and 
Table 1. Mean values, standard errors and $t$-statistics and $P$-values for the number of nests in each transect, the density of nests in each transect, the area inhabited by Trachymyrmex septentrionalis nests and the density of nests in these inhabited zones. Achieved power indicates the post hoc power of the statistical test. Significant $P$-values $(\alpha=0.05)$ are highlighted in bold. In all cases, $N=31$ and d.f. $=N-1$.

\begin{tabular}{|c|c|c|c|c|c|c|}
\hline Variable & $\begin{array}{l}2001 \\
(\text { mean } \pm \text { SD })\end{array}$ & $\begin{array}{l}2004 \\
(\text { mean } \pm \text { SD })\end{array}$ & $t$ & $P$-value & $\begin{array}{l}\text { Achieved } \\
\text { power }\end{array}$ & Cohen's $d$ \\
\hline Nest number & $107 \pm 96$ & $94 \pm 93$ & 2.264 & 0.03 & 0.60 & 0.15 \\
\hline Nest density (nests $\mathrm{m}^{-2}$ ) & $0.063 \pm 0.046$ & $0.054 \pm 0.04$ & 2.63 & 0.01 & 0.72 & 0.21 \\
\hline Zone area $\left(\mathrm{m}^{2}\right)$ & $958 \pm 669$ & $873 \pm 695$ & 3.08 & 0.004 & 0.91 & 0.13 \\
\hline Zone density (nests $\mathrm{m}^{-2}$ ) & $0.099 \pm 0.061$ & $0.093 \pm 0.054$ & 0.728 & 0.472 & 0.10 & 0.10 \\
\hline
\end{tabular}

Table 2. Mean number of nests per transect, sample sizes, results from paired $t$-tests, post hoc statistical power and effect sizes (Cohen's d) between years for the five sampling regions. In all cases, d.f. $=N-1$.

\begin{tabular}{|c|c|c|c|c|c|c|c|}
\hline Region & $\begin{array}{l}2001 \\
(\text { mean } \pm \mathrm{SD})\end{array}$ & $\begin{array}{l}2004 \\
(\text { mean } \pm \mathrm{SD})\end{array}$ & $N$ & $t$ & $P$-value & $\begin{array}{l}\text { Achieved } \\
\text { power }\end{array}$ & Cohen's $d$ \\
\hline Ant Paradise & $151 \pm 82.5$ & $123 \pm 52$ & 9 & 1.95 & 0.09 & 0.40 & 0.41 \\
\hline Borrow Pit & $41 \pm 63$ & $33 \pm 49$ & 12 & 1.15 & 0.28 & 0.19 & 0.14 \\
\hline Cut-Off & $107 \pm 42$ & $81 \pm 43$ & 5 & 2.26 & 0.09 & 0.41 & 0.61 \\
\hline Lost Lake & 363 & 395 & 1 & - & - & - & - \\
\hline Crawfordville & $143 \pm 106$ & $151 \pm 123$ & 4 & -0.55 & 0.62 & 0.07 & 0.063 \\
\hline
\end{tabular}

habitat zone area did. Whether density-dependent population regulation occurs in these populations is not known even though populations exhibit patterns consistent with density dependence (Seal \& Tschinkel, 2006, 2008).

The exact cause of nest mortality is unclear. It is not known whether these colonies died suddenly as a result of catastrophic flooding or died secondarily over a longer period while exposed to more humid soils. Our observations suggest that water tables can rise and fall quickly, because several shallow pits excavated to collect $T$. septentrionalis colonies for another project contained water within $20-30 \mathrm{~cm}$ of the surface. After heavy rains, water table levels can also fall 1-2 cm per day (W. R. Tschinkel, unpubl. data). Several attempts to collect colonies marked prior to Tropical Storm Allison failed: chambers were found but not ants or fungus garden. It was unlikely that the ants escaped by digging deeper nests since the water table was at the bottom of the excavation pit.

In our earlier study, we proposed that soil displacement is likely a main ecological effect that this species has on the pine forest ecosystem (Seal \& Tschinkel, 2006). The estimates of soil displacement (ca. $1 \mathrm{MT}$ of soil displaced per hectare per year) by Seal and Tschinkel (2006) were calculated using only data obtained in the spring, thus making these conservative estimates for an annual basis. The results of the present study indicate that these values are likely higher during droughts and lower in wetter periods. If droughts can increase population sizes, more colonies would cause a greater vertical movement of soil, thus soil fertility may be reduced over the long term (Haines, 1983; Jiménez \& Decaëns, 2006; Jiménez et al., 2008). On the other hand, larger populations would presumably grow larger gardens and produce greater amounts of nutrient-rich refuse, which could increase soil fertility and have beneficial outcomes on the plant community as reported in leaf-cutting ants and Trachymyrmex jamaicensis in Puerto Rico (Farji Brener \& Silva, 1995; Torres et al., 1999; Farji Brener \& Ghermandi, 2004).

A recent review highlighted that patterns of ant biodiversity show inconsistent responses to habitat change (Underwood \& Fisher, 2006), whereas focus on a handful of common species potentially illustrates community and ecosystem function (Armbrecht \& Ulloa-Chacon, 2003). Furthermore, not all ant species are picked up in pitfalls or baits among other passive collecting methods and this is certainly true for T. septentrionalis. For example, $T$. septentrionalis represented $<0.5 \%$ of the total pitfall trap contents in two recent ant biodiversity studies in the ANF, parts of which were conducted in or near Ant Paradise and Borrow Pit (Lubertazzi \& Tschinkel, 2003; King \& Tschinkel, 2008). Thus had an explicit colony-level approach not been adopted, the main finding in this study would have gone unnoticed. In addition to standard biodiversity surveys, future studies may wish to consider documenting the distribution of common ant species, with specific attention how they are influenced by ecological characteristics and how these patterns may vary as climate changes.

\section{Acknowledgements}

We thank Joshua King, Katrin Kellner and the anonymous referees for their comments in improving this manuscript. We also thank Michael Dueitt of the USDA Forest Service for providing us with schedules of prescribed burns in the Apalachicola National Forest. This project was partly supported by a FSU

(C) 2010 The Authors

Journal compilation (C) 2010 The Royal Entomological Society, Insect Conservation and Diversity, 3, 134-142 

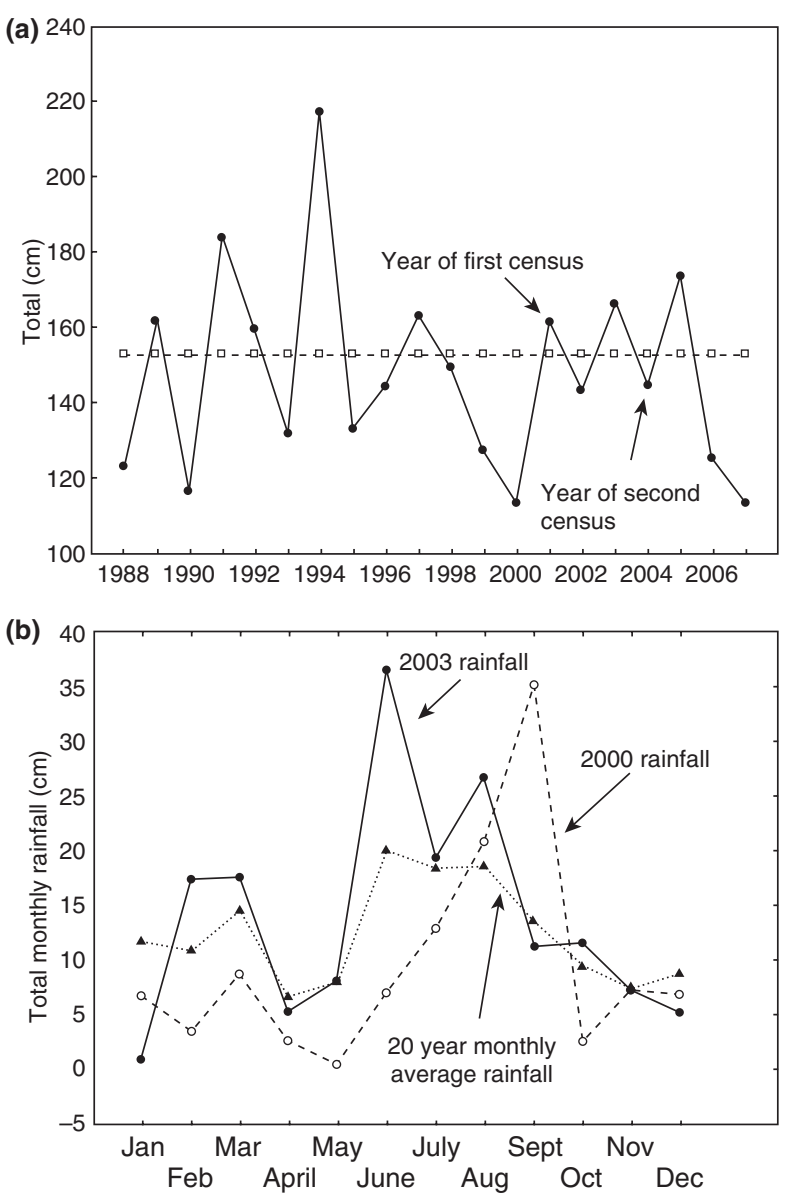

Fig. 4. (a) Total annual rainfall 1988-2007 and the mean rainfall for the same period $(152.76 \mathrm{~cm})$. This mean was not significantly different than the 113-year mean rainfall for Tallahassee $(150.38 \mathrm{~cm})(t$-test for single sample, $t=0.897, P=0.381)$. Although the total rainfall for 2001 was about average, most rainfall was associated with two tropical storms. (b) Mean monthly rainfall for 1988-2007. Most of 2000 was below average in terms of monthly rainfall, except for the two tropical storms in August and September, and 2003 was near or slightly above average in terms of monthly rainfall.

Dissertation Research Grant to JNS and carried out during the tenure of a Florida State University PEG (Program Enhancement Fund) Grant and NSF (IOS-0212085) Grant to WRT.

\section{References}

Abrahamson, W.G. \& Harnett, D.C. (1990) Pine flatwoods and dry prairies. The Ecosystems of Florida (ed. by R.L. Myers and J.J. Ewel), pp. 103-149. The University of Central Florida, Orlando, Florida.

Agosti, D., Majer, J.D., Alonso, L.E. \& Schultz, T.R. (2000) Ants: Standard Methods for Measuring and Monitoring Biodiversity. Smithsonian Institution, Washington, District of Columbia.
Andersen, A.N. (1997) Using ants as bioindicators: multiscale issues in ant community ecology. Conservation Ecology, 1, 8.

Aresco, M.J. (2005) Mitigation measures to reduce highway mortality of turtles and other herpetofauna at a north Florida lake. Journal of Wildlife Management, 69, 549-560.

Armbrecht, I. \& Ulloa-Chacon, P. (2003) The little fire ant Wasmannia auropunctata (Roger) (Hymenoptera: Formicidae) as a diversity indicator of ants in tropical dry forest fragments of Colombia. Environmental Entomology, 32, 542-547.

Banschbach, V.S. \& Herbers, J.M. (1999) Nest movements and population spatial structure of the forest ant Myrmica punctiventris (Hymenoptera: Formicidae). Annals of the Entomological Society of America, 92, 414-423.

Beckage, B., Platt, W.J., Slocum, M.G. \& Panko, B. (2003) Influence of the El Niño southern oscillation on fire regimes in the Florida Everglades. Ecology, 84, 3124-3130.

Blaustein, R.J. (2008) Biodiversity Hotspot: The Florida Panhandle. BioScience, 58, 784-790.

Bollazzi, M., Kronenbitter, J. \& Roces, F. (2008) Soil temperature, digging behavior, and the adaptive value of nest depth in South American species of Acromyrmex leaf-cutting ants. Oecologia, 158, 165-175.

Bollazzi, M. \& Roces, F. (2002) Thermal preference for fungus culturing and brood location by workers of the thatching grass-cutting ant Acromyrmex heyeri. Insectes Sociaux, 49, 153157.

Bourke, A.F.G. \& Franks, N.R. (1995) Social Evolution in Ants. Princeton University Press, Princeton, New Jersey.

Brian, M.V. \& Brian, A.D. (1951) Insolation and ant populations in the west of Scotland. Transactions of the Royal Entomological Society of London, 102, 303-330.

Brown, R.B., Stone, E.L. \& Carlisle, V.W. (1990) Soils. Ecosystems of Florida (ed. by R.L. Myers and J.J. Ewel), pp. 35-69. University of Central Florida Press, Orlando, Florida.

Cammeraat, E.L.H. \& Risch, A.C. (2008) The impact of ants on mineral soil properties and processes at different spatial scales. Journal of Applied Entomology, 132, 285-294.

Carlson, D.M. \& Gentry, J.B. (1973) Effects of shading on the migratory behavior of the Florida Harvester Ant, Pogonomyrmex badius. Ecology, 54, 452-453.

Cerdá, X., Retana, J. \& Cros, S. (1998) Critical thermal limits in Mediterranean ant species: trade-off between mortality risk and foraging performance. Functional Ecology, 12, 45-55.

Chen, E. \& Gerber, J.F. (1990) Climate. Ecosystems of Florida (ed. by R.L. Myers and J.J. Ewel), pp. 11-34. University of Central Florida Press, Orlando, Florida.

Chown, S.L. \& Nicholson, S.W. (2004) Insect Physiological Ecology: Mechanisms and Patterns. Oxford University Press, Oxford, UK

Davidson, D.W., Cook, S.C., Snelling, R.R. \& Chua, T.H. (2003) Explaining the abundance of ants in lowland tropical rainforest canopies. Science, 300, 969-972.

Delsinne, T., Leponce, M., Theunis, L., Braet, Y. \& Roisin, Y. (2008) Rainfall influences ant sampling in dry forests. Biotropica, 50, 590-596.

Deutsch, C.A., Tewksbury, J.T., Huey, R.B., Sheldon, K.S., Ghalambor, C.K., Haak, D.C. \& Martin, P.R. (2008) Impacts of climate warming on terrestrial ectotherms across latitude. Proceedings of the National Academy of Sciences, USA, 105, 66686672.

Deyrup, M. \& Lubertazzi, D. (2001) A new species of ant from North Florida (Hymenoptera: Formicidae). Entomological News, 112, 15-21. 
Dingemanse, N.J. \& Kalkman, V.J. (2008) Changing temperature regines have advanced the phenology of Odonata in the Netherlands. Ecological Entomology, 33, 394-402.

Elmes, G.W. \& Wardlaw, J.C. (1982a) A population study of the ants Myrmica sabuleti and Myrmica scabrinodis, living at two sites in the south of England. I. A comparison of colony populations. Journal of Animal Ecology, 51, 651-664.

Elmes, G.W. \& Wardlaw, J.C. (1982b) A population study of the ants Myrmica sabulleti and Myrmica scabrinodis living at two sites in the south of England. II. Effect of above-nest vegetation. Journal of Animal Ecology, 51, 665-680.

Espeleta, J.F. \& Donovan, L.A. (2002) Fine root demography and morphology in response to soil resources availability among xeric and mesic sandhill tree species. Functional Ecology, 16, 113-121.

Farji Brener, A.G. \& Ghermandi, L. (2004) Seeding recruitment in a semi-arid Patagonian steppe: facilitative effects of refuse dumps of leaf-cutting ants. Journal of Vegetation Science, 15, 823-830.

Farji Brener, A.G. \& Silva, J.F. (1995) Leaf-cutting ant nests and soil fertility in a well-drained savanna in western Venezuela. Biotropica, 27, 250-254.

Faul, F. (2008) GPOWER: A Priori, Post-hoc, and Compromise Power Analyses. Universität Kiel, Kiel, Germany.

Folgarait, P.J. (1998) Ant biodiversity and its relationship to ecosystem functioning: a review. Biodiversity and Conservation, 7, $1221-1244$.

Frost, C.C. (1993) Four centuries of changing landscape patterns in the longleaf pine ecosystem. Proceedings of the Tall Timbers Fire Ecology Conference. No. 18, The Longleaf pine Ecosystem: Ecology, Restoration, and Management (ed. by S. Hermann), pp. 17-43. Tall Timbers Research Station, Tallahassee, Florida.

Glitzenstein, J.S., Platt, W.J. \& Streng, D.R. (1995) Effects of fire regime and habitat on tree dynamics in North Florida Longleaf Pine Savannas. Ecological Monographs, 65, 441-476.

Haines, B. (1983) Leaf-cutting ants bleed mineral elements out of rainforest in southern Venezuela. Tropical Ecology, 24, $85-93$.

Harrison, J.S. \& Gentry, J.B. (1981) Foraging pattern, colony distribution, and foraging range of the Florida Harvester Ant, Pogonomyrmex badius. Ecology, 62, 1467-1473.

Hickling, R., Roy, D.B., Hill, J.K. \& Thomas, C.D. (2005) A northward shift of range margins in British Odonata. Global Change Biology, 11, 502-506.

Hölldobler, B. \& Wilson, E.O. (1990) The Ants. Harvard University Press, Cambridge, Massachussetts.

Hölldobler, B. \& Wilson, E.O. (2008) The Superorganism: The Beauty, Elegance and Strangeness of Insect Societies. W.W. Norton and Company, New York, New York.

Hood, W.G. \& Tschinkel, W.R. (1990) Dessication resistance in arboreal and terrestrial ants. Physiological Entomology, 15, 23 35 .

Jiménez, J.J. \& Decaëns, T. (2006) Chemical variation in the biostructures produced by soil ecosystem engineers. Examples from the neotropical savannas. European Journal of Soil Biology, 42, S92-S102.

Jiménez, J.J., Decaëns, T. \& Lavelle, P. (2008) C and N concentrations in biogenic structures of a soil-feeding termite and a fungus-growing ant in the Colombian savannas. Applied Soil Ecology, 40, 120-128.

Johnson, R.A. (2001) Biogeography and community structure of North American seed-harvester ants. Annual Review of Entomology, 46, 1-29.
Jouquet, P., Dauber, J., Lagerlöf, J., Lavelle, P. \& Lepage, M. (2007) Soil invertebrates as ecosystem engineers: intended and accidental effects on soil and feedback loops. Applied Soil Ecology, 32, 153-164.

Kaspari, M., Alonso, L. \& O'Donnell, S. (2000) Three energy variables predict ant abundance at a geographical scale. Proceedings of the Royal Society B: Biological Sciences, 267, 485490

Kindvall, O. (1995) The impact of extreme weather on habitat preference and survival in a metapopulation of the bush cricket Metrioptera bicolor in Sweden. Biological Conservation, 73, 5158.

King, J.R. \& Trager, J.C. (2007) Natural history of the slave making ant, Polyergus lucidus, sensu lato in northern Florida and its three Formica pallidefulva group hosts. Journal of Insect Science, 7. Available from URL: http://www.insectscience.org/ 7.42 .

King, J.R. \& Tschinkel, W.R. (2008) Experimental evidence that human impacts drive fire ant invasions and ecological change. Proceedings of the National Academy of Sciences, USA, 105, 20339-20343.

Lawrimore, J., Halpert, M., Bell, G., Menne, M., Lyon, B., Schnell, R., Gleason, K., Easterling, D., Thiaw, W., Wright, W., Heim, R., Robinson, D. \& Alexander, L. (2001) Climate assessment for 2000. Bulletin of the American Meteorological Society, 86, S1-S55.

Long, T.J. \& Jones, R.H. (1996) Seedling growth strategies and seed size effects in fourteen oak species native to different soil moisture habitats. Trees, 11, 1-8.

Lubertazzi, D. \& Tschinkel, W.R. (2003) Ant community change across a ground vegetation gradient in north Florida's longleaf pine flatwoods. Journal of Insect Science, 3, 17

MacMahon, J.A., Mull, J.F. \& Crist, T.O. (2000) Harvester ants (Pogonomyrmex spp.): their community and ecosystem influences. Annual Review of Ecology and Systematics, 31, 265-291.

McGlynn, T.P., Carr, R.A., Carson, J.H. \& Buma, J. (2004) Frequent nest relocation in the ant Aphaenogaster araneoides: resources, competition, and natural enemies. Oikos, 106, 611621.

Means, D.B. (2007) Life Cycles, Dispersal, and Critical Habitat Utilization of Vertebrates Dependent upon Small Isolated Water Bodies in the Munson Sandhills and Woodville Karst Plain, Leon County, Florida. Department of Transportation for OMNI Project 010562, Tallahassee, Florida.

Mueller, U.G., Schultz, T.R., Currie, C.R., Adams, R.M.M. \& Malloch, D. (2001) The origin of the attine ant-fungus mutualism. The Quarterly Review of Biology, 76, 169-197.

Myers, R.L. (1990) Scrub and high Pine. The Ecosystems of Florida (ed. by R.L. Myers and J.J. Ewel), pp. 150-193. The University of Central Florida, Orlando, Florida.

Nakagawa, S. \& Cuthill, I.C. (2007) Effect size, confidence interval and statistical significance: a practical guide for biologists. Biological Reviews, 82, 591-605.

NOAA: Climate Prediction Data Center (2009) Cold and Warm Episodes by Season 1950-2009. National Weather Service, Camp Springs, Maryland, February 4, 2009.

Parmesan, C. (2006) Ecological and evolutionary responses to recent climate change. Annual Review of Ecology and Systematics, 37, 637-669.

Parmesan, C., Ryrholm, N., Stefanescu, C., Hill, J.K., Thomas, C.D., Descimon, H., Huntley, B., Kaila, L., Kullberg, J., Tammaru, T., Tennett, W.J., Thomas, J.A. \& Warren, M. (1999) 
Poleward shifts in geographical ranges of butterfly species associated with regional warming. Nature, 399, 579-583.

Platt, W.J. (1999) Southeastern pine savannas. Savanna, Barren, and Rock Outcrop Communities of North America (ed. by R.C. Anderson, J.S. Fralish and J. Baskin), pp. 23-51. Cambridge University Press, Cambridge, UK.

Pollard, E., Greatorex-Davies, J.N. \& Thomas, J.A. (1997) Drought reduced breeding successs of the butterfly Aglais urticae. Ecological Entomology, 22, 315-318.

Powell, R.J. \& Stradling, D.J. (1986) Factors influencing the growth of Attamyces bromatificus, a symbiont of attine ants. Transactions of the British Mycological Society, 87, 205-213.

Rabeling, C., Cover, S.P., Johnson, R.A. \& Mueller, U.G. (2007) A review of the North American species of the fungus-gardening ant genus Trachymyrmex (Hymenoptera: Formicidae). Zootaxa, 1664, 1-53.

Roces, F. \& Kleineidam, C. (2000) Humidity preference for fungus culturing by workers of the leaf-cutting ant Atta sexdens rubropilosa. Insectes Sociaux, 47, 348-350.

Seal, J.N. \& Tschinkel, W.R. (2006) Colony productivity of the fungus-gardening ant, Trachymyrmex septentrionalis McCook, in a Florida pine forest (Hymenoptera: Formicidae). Annals of the Entomological Society of America, 99, 673-682.

Seal, J.N. \& Tschinkel, W.R. (2007) Energetics of newly mated queens and colony founding in the fungus-gardening ants Cyphomyrmex rimosus and Trachymyrmex septentrionalis (Hymenoptera: Formicidae). Physiological Entomology, 32, 815

Seal, J.N. \& Tschinkel, W.R. (2008) Food limitation in the fungus-gardening ant, Trachymyrmex septentrionalis. Ecological Entomology, 33, 597-607.

Sokal, R.R. \& Rohlf, F.J. (1995) Biometry. W.H. Freeman and Co., New York, New York.

Statsoft (2003) STATISTICA (Data Analysis Software System). Statsoft, Tulsa, Oklahoma.

Thomas, C.D., Bodsworth, E.J., Wilson, R.J., Simmons, A.D., Davies, Z.G., Musche, M. \& Conradt, L. (2001) Ecological and evolutionary processes at expanding range margins. Nature, 411, 577-581.

Tobin, J.E. (1994) Ants as primary consumers: diet and abundance in the Formicidae. Nourishment and Evolution in Insect Societies (ed. by J.H. Hunt and C.A. Nalepa), pp. 279-307. Westview, Boulder, Colorado.

Torres, J.A., Santiago, M. \& Salgado, M. (1999) The effects of the fungus-growing ant, Trachymyrmex jamaicensis, on soil fertility and seed germination in a subtropical dry forest. Tropical Ecology, 40, 237-245.

Tschinkel, W.R. (1987) Seasonal life history and nest architecture of a winter active ant, Prenolepis imparis. Insectes Sociaux, 34, 143-164.

Tschinkel, W.R. (1988) Distribution of the fire ants Solenopsis invicta and S. geminata (Hymenoptera: Formicidae) in Northern Florida in relation to habitat and disturbance. Annals of the Entomological Society of America, 81, 76-81.
Tschinkel, W.R. (1999) Sociometry and sociogenesis of colonylevel attributes of the Florida Harvester Ant (Hymenoptera: Formicidae). Annals of the Entomological Society of America, 92, 80-89.

Tschinkel, W.R. (2003) Subterranean ant nests: trace fossils past and future? Palaeogeography, Palaeoclimatology, Palaeoecology, 192, 321-333.

Tschinkel, W.R. (2004) The nest architecture of the Florida harvester ant, Pogonomyrmex badius. Journal of Insect Science, 4, 21, Available from URL: insectscience.org/4.21

Tschinkel, W.R. (2005) The nest architecture of the ant, Camponotus socius. Journal of Insect Science, 5, 9. Available from URL: insectscience.org/5.9

Tschinkel, W.R. (2006) The Fire Ants. Harvard University Press, Cambridge, Massachussetts.

Tschinkel, W.R. \& Bhatkar, A. (1974) Oriented mound building in the ant, Trachymyrmex septentrionalis. Environmental Entomology, 3, 667-673.

Underwood, E.C. \& Fisher, B.L. (2006) The role of ants in conservation monitoring: if, when, and how. Biological Conservation, 132, 166-182.

Verdi, R.J., Tomlinson, S.A. \& Marella, R.L. (2006) The Drought of 1998-2002: Impacts on Florida's Hydrology and Landscape. US Geological Survey Circular 1295, Reston, Virginia.

Waite, W.R. (1984) Soils and Vegetation of the Apalachicola National Forest. United States Department of Agriculture, Forest Service, Southern Region, Atlanta, Georgia.

Waldron, J.L., Welch, S.M. \& Bennett, S.H. (2008) Vegetation structure and the habitat specificity of a declining North American reptile: a remnant of former landscapes. Biological Conservation, 141, 2477-2482.

Whitney, E., Means, D.B. \& Rudloe., A.R. (2004) Priceless Florida: Natural Ecosystems and Native Species. Pineapple Press, Melbourne, Florida.

Williams, K., MacDonald, M. \& da Silveira Lobo Sternberg, L. (2003) Interactions of storm, drought, and sea-level rise on coastal forests: a case study. Journal of Coastal Research, 19, $1116-1121$

Williams, K., MacDonald, M., McPherson, K. \& Mirti, T.H. (2007) Ecology of the coastal edge of hydric hammocks on the Gulf Coast of Florida. Ecology of Tidal Freshwater Forested Wetlands of the Southeastern United States (ed. by W.H. Conner, T.W. Doyle and K.W. Krauss), pp. 255-289. Springer, New York, New York.

Accepted 29 January 2010

First published online 11 March 2010

Editor: Yves Basset

Associate editor: Jacobus Boomsma 